Jurnal ISLAMIKA, Vol. 3, No. 2 (2020): 14-23

\title{
Keuangan Publik Dalam Perspektif Ekonomi Islam
}

\author{
Tina Arfah \\ Institut Agama Islam Negeri Padangsidimpuan \\ Tinaarfah89@gmail.com \\ Putri Jamilah \\ Universitas Muhammadiyah Riau \\ putrijamilah@yahoo.co.id
}

\begin{abstract}
In a country based on capitalism we will find many problems in the country's economy . This is due to the management of State finances both in terms of income The state and state expenditures are not as expected by the community, there are still many elements of fraud, corruption, etc.. financial management like this will result in an economic crisis and create misery for the community. to overcome this problem the government must use an economic concept that can overcome this problem., The concept that can be applied by the government is public finance in an Islamic economic perspective. Islamic economic concepts have been proven to improve justice and welfare in society.
\end{abstract}

Keyword: public benefit, expenditure, welfare income

\begin{abstract}
ABSTRAK
Di negara yang berbasis kapitalisme kita akan menemukan banyak masalah dalam perekonomian negara tersebut. Hal ini dikarenakan pengelolaan keuangan negara baik dari segi pendapatan maupun belanja negara belum sesuai dengan yang diharapkan masyarakat, masih banyak unsur penipuan, korupsi, dll. Pengelolaan keuangan seperti ini akan mengakibatkan terjadinya krisis ekonomi dan menimbulkan kesengsaraan bagi masyarakat. Untuk mengatasi masalah tersebut pemerintah harus menggunakan suatu konsep ekonomi yang dapat mengatasi masalah tersebut. Konsep yang dapat diterapkan oleh pemerintah adalah keuangan publik dalam perspektif ekonomi Islam. Konsep ekonomi Islam terbukti mampu meningkatkan keadilan dan kesejahteraan masyarakat.
\end{abstract}

\section{PENDAHULUAN}

Kondisi perekonomian merupakan indikator utama dalam mengukur tingkat kesejahteraan suatu masyarakat. Sebuah negara akan dipandang sebagai negara yang sejahtera manakala memiliki sistem ekonomi yang mapan dan memiliki pendapatan yang mencukupi. Sebaliknya, kondisi perekonomian yang carut-marut, banyak warga yang berada di bawah garis kemiskinan, jutaan rakyat menganggur, maka negara tersebut tidak 
dapat dikatakan negara sejahtera. Paradigma inilah yang menjadikan ilmu ekonomi sebagai ilmu yang paling penting dalam kehidupan manusia. Berbagai teori dikemukakan oleh para ahli dan para pemikir dari zaman Yunani hingga saat ini. Semua teori dan pandangan tersebut diperuntukkan membangun masyarakat yang lebih berkeadilan dan lebih sejahtera(Ofan El-Govha.2009).

Pasal 33 ayat (3) UUD 1945, disebutkan bahwa bumi, air, dan kekayaan alam yang terkandung di dalamnya dikuasai oleh negara dan dipergunakan untuk sebesar-besarnya kemakmuran rakyat. Hal ini mengandung arti bahwa pemerintah sebagai pengelola negara diberikan mandat untuk mengelola aset-aset negara, sehingga aset-aset tersebut dapat menjadi sumber pendapatan negara. Pendapatan negara ini yang kemudian digunakan untukmembiayai kegiatan pemerintah dalam melaksanakan kebijakan-kebijakannya. Penerimaan dan pengeluaran yang berkaitan dengan keuangan negara harus diatur.Jadi sudah jelas tujuan dari sebuah pemerintahan yaitu untuk mensejahteraakan kehidupan masyarakat .untuk memenuhi kebutuhan masyarat maka pemerintah harus mengatur keuangan public secara adil ,jujur dan tranparan.

Keuangan publik dalam konteks syariah menjadi bagian yang tidak terpisahkan dari kehidupan manusia dalam bermuamalah khususnya hubungan relasi negara dengan rakyatnya, yang kelak akan dipertanggungjawabkan dihadapan Allah s.w.t, sebab dalam islam tidah hanya mengkaji mengenai ibadah saja atau hubungan spiritual tetapi dalam islam mengkaji seluruh aspek kehidupan manusia baik dalam hal kecil maupun besal. Namun realitanya untuk sekarang ini pengelolaan keuangan publik tidak sesuai tuntunan syariah. Maka dengan itu perlu dikaji bagaimana tata cara mengelola keuangan publik dalam perspektif ekonomi Islam.

\section{Teori Yang Relevan}

Keuangan negara menurut van der kemp (dikutip oleh Nia K. Winayanti,2015:10) adalah semua hak yang dapat dinilai dengan uang, demikian pula segala sesuatu (baik berupa uang maupun barang) yang dapat dijadikan milik negara berhubungan dengan hakhak tersebut Menurut Arifin P. Soeria (1986) Atmadja mendefinisikan keuangan negara dari segi pertanggungjawaban oleh pemerintah, bahwa keuangannegara yang harus dipertanggungjawabkan oleh pemerintah adalah keuangan negara yang hanya berasal dari APBN. Sehingga yang dimaksud dengan keuangan negara adalah keuangan yang berasal dari APBN.Arifin P. Soeria Atmadja menggambarkan dualisme pengertian keuangan negara, yakni pengertian keuangan negara dalam arti yang luas dan pengertian keuangan negara dalam arti yang sempit.4Pengertian keuangan negara dalam arti luas yang dimaksud adalah keuangan yang berasal dari APBN, APBD, Keuangan Unit-unit Usaha Negara atau perusahaan-perusahaan milik negara dan pada hakikatnya seluruh kekayaan negara. Sedangkan pengertian keuangan negara dalam arti sempit adalah keuangan yang berasal dari APBN saja. 
Adapun keuangan publik "normative" adalah studi keuangan Negara tentang etika dan nilai pandang (value judgement), yakni bagaimana kegiatan keuangan negara, perpajakan, pengeluaran dan pinjaman negara bias menciptakan efisiensi alokasi sumber daya, stabilisasi ekonomi makro,pemerataan atau distribusi pendapatan dan lain sebagainya. Jadi, studi "normativepublic finance" lebih banyak berkisar pada daerah permasalahan kebijakan keuangan negara (fiscal policy) (Harvey S. Rossen, 2002:5) Dalam hal ini, kebijakan pemerintah terkait dengan penerimaan dan pengeluaran untuk memperbaiki stabilitas ekonomi perlu dilakukan dalambentuk kebijakan fiskal (fiscal policy). Menurut Soediyono R.,58 kebijakan fiscal atau politik fiskal merupakan tindakan yang diambil pemerintah dalam bidang anggaran belanja negara berupa penerimaan dan pengeluaran dengan tujuan untuk mempengaruhi jalannya perekonomian Sedangkan keuangan public dalam Islam adalah sebuah kebijakan pemerintah dalam mengelolah keuangan Negara baik dari segi pengeluaran, pendapatan sesuai dengan prinsip syaiah,yaitu adil, jujur dan tranparan sehingga masyarakat sejahtera.

\section{Ekonomi Islam}

Ekonomi, secara umum didefinisikan sebagai hal yang mempelajari aktivitas manusia dalam menggunakan sumber daya yang langka untuk memproduksi barang dan jasa yang dibutuhkan manusia (Pusat Pengkajian dan Pengembangan Ekonomi Islam (P3EI), 2011, h:14). Menurut Chapra (dikutip Mustafa Edwin Nasution dkk, 2006: 16) ekonomi Islam adalah sebuah pengetahuan yang membantu upaya realisasi kebahagiaan manusia melalui alokasi dan distribusi sumber daya yang terbatas yang berada dalam koridor yang mengacu pada pengajaran Islam tanpa memberikan kebebasan individu atau tanpa perilaku makro ekonomi yang berkesinambungan dan tanpa ketidakseimbangan lingkungan.

Dari uraian diatas dapat diartikan bahwa ekonomi islah adalah suatu aktivitas manusia dalam menggunakan sumber daya untuk memproduksi barang dan jasa sesuai dengan prinsip islam.adapun prinsip ekonomi Islam yaituMuslim H. Kara, Khurshid Ahmad (2005, 37-38) mengkategorisasi prinsip-prinsip ekonomi Islam pada: Prinsip tauhid, rubbiyyah, khilafah, dan tazkiyah.Mahmud Muhammad Bablily menetapkan lima prinsip yang berkaitan dengan kegiatan ekonomi dalam Islam, yaitu: al-ukhuwwa (persaudaraan), alihsan (berbuat baik), al-nasihah (memberi nasihat), al-istiqamah (teguh pendirian), dan altaqwa (Mahmud Muhammad Bablily, 1990:15).

Adapun perbedaan ekonomi islam dan ekonomi konvensiaonal dapat dilihat dari sumber, kepemilikan ,tujuan kehiduannya,distribusi pendapatan dll. Di bawah ini akan dipaparkan dengan jelas perbedaan antara sistem ekonomi Islam, Kapitalis dan Sosialis dalam menjawab permasalahan pokok suatu sistem. Adapun tabel perbedaan antara sistem Ekonomi sebagai berikut: 


\begin{tabular}{|l|l|l|}
\hline Indicator & Islam & Kapitalis \\
\hline Sumber & $\begin{array}{l}\text { Al-qur'an } \\
\text { dan as- } \\
\text { sunnah }\end{array}$ & Akal manusia \\
\hline Kepemilikan & $\begin{array}{l}\text { Allah } \\
\text { pemilik } \\
\text { mutlak dan } \\
\text { manusia } \\
\text { memiliki hak } \\
\text { terbatas }\end{array}$ & $\begin{array}{l}\text { Manusia memiliki } \\
\text { kepemilikan mutlak }\end{array}$ \\
\hline Pemanfaatan & $\begin{array}{l}\text { Pemanfaata } \\
\text { n mengikuti } \\
\text { ketentuan } \\
\text { Allah }\end{array}$ & $\begin{array}{l}\text { Manusia } \\
\text { memanfaatkan demi } \\
\text { keuntungan }\end{array}$ \\
\hline $\begin{array}{l}\text { Tujuan } \\
\text { kehidupan }\end{array}$ & $\begin{array}{l}\text { Falah dunia } \\
\text { akhirat }\end{array}$ & $\begin{array}{l}\text { Profit oriented } \\
\text { Distribusi } \\
\text { pendapatan }\end{array}$ \\
$\begin{array}{l}\text { Berdasarkan } \\
\text { pada pasar, } \\
\text { pemerintah } \\
\text { dan } \\
\text { masyarakat }\end{array}$ & $\begin{array}{l}\text { Berdasarkan pada } \\
\text { mekanisme pasar }\end{array}$ \\
\hline
\end{tabular}

Sumber: diolah dari berbagai sumber Mustafa Edwin Nasution dkk(2006) M. A Mannan (1997)

\section{METODOLOGI}

Penelitian ini merupakan penelitian kualitatif dan menggunakan penelitian kepustakaan (Library Reseach). Penelitian kualitaif adalah prosedur penelitian yang menghasilkan data deskriptif berupa kata- kata tertulis atau lisan dari orang - orang dan perilaku yang dapat diamati Menurut Moleong (2008: 9). Metodologi penelitian ini disebut penelitian kualitatif karena mempertahankan orisinilitas data dalam bentuknya yang kualitatif .Sumber data dalam penelitian terdiri dari data primer dan data sekunder.adapun sumber data primer dalam penelitian ini adalah buku karya Ibnu taimiyah buku karya Abu Ubaid al-Qasim "al-Amwal (Harta) Ensiklopedia Keuangan Public dan buku karya Ibnu Taimiyah " Hisbah Pengawasan Publik " Data sekunder dalam penelitian ini digunakan untuk melengkapi dan mendukung informasi objek penelitian baik yang berbentuk buku, karya tulis, dan artikel yang berhubungan dengan objek penelitian. Metode pengumpulan data yang digunakan dalam penelitian ini adalah meto de dokumentasi data yang diperoleh dalam penelitian ini lebih lanjut dianalisis dengan menggunakan metode kajian isi (content analisis) atau sering dikatakan sebagai analisis isi 
sevara kualitatif.yaitusuatu teknik sistematk untuk menganalisis pesan dan mengolahnya kemudian menarik kesimpulan.

\section{Studi Penelitian Terdahulu}

Mohammad Ghozali dan Ria Khoirunnisa dengan judul Konsep Pengelolaan Keuangan Islam Menurut Pemikiran Abu Ubaid (Jurnal Ekonomi dan Bisnis Islam, Vol. 4, No. 1, Januari-Juni 2018)menjelaskan bahwa Pandangan-pandangan Abu Ubaid merefleksikan perlunya memelihara dan mempertahankan hak dan kewajiban masyarakat, menjadikan keadilan sebagai prinsip utama dalam menjalankan roda kebijakan pemerintah, serta menekankan rasa persatuan dan anggung jawab bersama. Disamping itu, menyatakan bahwa pemerintah wajib memberikan jaminan standar kehidupan yang layak bagi setiap individu dalam sebuah masyarakat muslim. 0-mengatakan bahwa penerimaan negara (fai', khumus, shadaqah dan zakat) wajib dikelolah negara dan mengalokasikannya kepada masyarakat.

Aan Jaelani Relasi dengan Negara Dan Pasar Bebas Dalam Mewujudkan Keadilan Ekonomi: Analisis Sejarah Keuangan Publik Islam (Al-Mustashfa: Jurnal Penelitian Hukum Ekonomi Islam Vol. 3, No. 2, Desember 2018 ) menjelaskan bahwa relasi negara dan pasarbebas harus dapat diimplementasikan dalam berbagai kebijakan politik pemerintah dalam mengelola keuangan yang dapat mewujudkan kesejahteraan ekonomi. Dalam sejarahnya, prioritas fungsi masyarakat menjadi indikator pembangunan yang seca peran pemerintah memiliki arti penting dalam mengatur mekanisme pasar dan menolak pasar bebas yang jelas merugikan rakyat. Bagaimanapun juga secara syari"ah, pemerintah berperan dalam pemenuhan kebutuhan dan pelayanan sosial bagi masyarakat. Mengutip Sri- Edi Swasono, negara harus turut campur tangan dan tidak menitipkan nasib rakyat dankepentingan negara kepada selera dan kehendak pasar bebas. Tidak hanya itu, Negara diharapkan mampu mendesain dan menata perekonomian agar terwujud kesejahteraan dan keadilan sosial di tengah masyarakat. Jadi, kebersamaan dan kerja sama menjadi kunci jawaban karena bagaimanapun demokrasi ekonomi yang mementingkan masyarakat (public-interest atau social-interest) lebih utama disbanding kepentingan orang- perorang (self-interest).

M. Zia Ulhaq dengan judul "Pengelolaan Keuangan Publik Islam (Umar Bin Abdul Aziz) AMAL: Journal of Islamic Economic And Business (JIEB) Vol. 02, No. 01 tahun 2020. Pengelolaan keuangan publik sangat diperhatikan karena membicarakan masalah kemaslahatan umat serta dengan pengelolaan keuangan publik yang maksimal, maka akan dapat membawa mencapai tujuan hidup masyarakat adalah kemakmuran atau kesejahteraan. Dapat dilihat dari sudut pandang historis dalam pengelolaan keuangan publik pada periode Umar bin Abdul Aziz, pada masa Umar bin Abdul Aziz adalah mengelola keuangan publik dengan baik hingga sulit ditemukan orang miskin penerima zakat. Salah satu kunci kesuksesan Umar bin Abdul Aziz dalam menjalankan roda pemerintahannya adalah sinerginya dengan para ulama. Kesuksesan kebijakan yang 
dilakukan oleh Umar bin Abdul Aziz adalah mengembalikan hak-hak rakyat yang pernah diambil oleh pejabat secara dzalim, mencetuskan ekonomi bebas terikat, perhatian Umar dalam bidang pertanian, menghapuskan pajak yang memberatkan, membangun fasilitas umum.

Fathul Aminudin Aziz dengan judul Hukum Denda Dalam Keuangan Publik Islam Di Indonesia (julnal al-manahij Vol. XII No. 2 Desember 2018 menjelaskan bahwa dalam rangka mentaati perintah pemerintah seperti dipesankan dalam hadits, dan dalam rangka kontribusi mewujudkan kemaslahatan bersama dalam hidup bernegara. Adapun besaran denda, maka pemerintah tidak boleh sesuka hati menentukan denda yang terlalu besar sehingga memberatkan rakyat. Akan tetapi sekiranya cukup sebagai pesan teguran dan menutupi kekurangan APBN. Oleh karenanya jika dengan keterlambatan pembayaran keuangan negara masih stabil, maka pemerintah hendaknya mengeluarkan kebijakan bebas denda

\section{HASIL DAN PEMBAHASAN}

Pengaturan keuangan public merupakan suatu kegiatan eknomi yang penting untuk diperhatikan pememerintah.keuangan public bertujuan untuk mengatur tentang penerimaan dan pengeluaran Negara.jika keuangan public tidak dikelolah dengan baik maka akan menimbulkan damapak yang buruk terhadapa perekonomian, tetapi sebalikknya jika keuaangan public dikelola dengan baik akan memberikan dampak positif terhadap Negara misalnya dapat meningkatkan kesejahteraan dan keadilan masyarakat.

Pengelolahan keuangan public secara konvensial yang selama ini menjadi pedoman dunia, ternyata sudah tidak dapat lagi mempertahankan kekuatan ekonomi, hal ini dapat dilihat dari terjadinya krisis global di Negara- Negara adikuasa di Eropa dan Amerika. Masyarakat sudah mempertanyakan pengaturan keuangan public Konvensional , sehingga dibutuhkanlah sistem ekonomi Islam yang bisa menjadi pedoma dalam pengelolahan keuangan Negara. Dalam ekonomi Islam sitem pengelolahan keuangan Negara damapt dilihat dari segi pendapatan Negara dan pengeluaran negaran.

Adapun pendapatan Negara dalam ekonomi Islam sebagai berikut:

1. zakat

Secara bahasa, zakat berasal dari kata "الزكاة- بـ زكى- زكى "yang berarti suci, tumbuh, berkah, dan terpuji (Ibnu Manzur,1990:35).Dalam buku Pedoman Zakat, zakat menurut bahasa berarti nā̄"(kesuburan), thah̄rah (kesucian), barakah (keberkahan), dan juga tazkiyahtath $\bar{h}$ /mensucikan(Hasbi Ash-Shiddieqy.1984:24). Dalam Kamus AlKautsar zakat berarti tumbuh bertambah, berkembang. Jadi zakat menurut bahasa dapat diartikan bahwa harta yang telah dikeluarkan seseorang dengan tujuan untuk menjadikan harta itu subur, suci dan berkah.zakat itu merupakan ketentuan yang wajib diberikan umat muslim kepada mustahiq zakat jika sudah mencapai haul dan 
nisab.adapun golongan yang behak meneima zakat (mustahiq zakat) yaitu: fakir, miskin, Amil, muallaf, Raqib(budak), fisabilillah dan ibnu sabil.

Zakat itu tebagi dua yaitu zakat fitrah dan zakat mal. Zakat mal adalah harta yang wajib dikeluarkan umat Islam ketika sudah mencapai haul dan nisab.Zakat fitrah adalah zakat yang wajib dikeluarkan umat muslim pada bulan ramadhan sampai menjelang idul fitri yang bertujuan untuk mensucikan diri dari perbuatan dosa. Sedatkan zakat mal zakat Abu Ubaid mengungkapkan ketentuan yang disepakati (tidak adaikhtilaf), yaiyang wajib dikeluarkan umat muslim ketika sudah mencapi halu dan nisab. apabila seseorang memiliki harta yang wajib dizakati diantaranya 200 dirham, 20 dinar, 5 ekor unta, 30 ekor sapi, atau 40 ekor kambing. Konsekuensinya, bila seseorang memiliki salah satu di atas dari awal haul sampai akhir, maka ia wajib mengeluarkan zakatnya yang dinamakan nishab oleh Imam Malik dan penduduk Madinah sedangkan penduduk Iraq menyebutnya asal harta (Abu ubaid.2006:512).

\section{Fa'i}

Secara bahasa fay' berarti mengembalikan sesuatu (Ibn Manzhur: 30).Fay' diperoleh daribarang yang dirampas dan orang-orang tidak beriman yang takluk tanpa peperangan (Al-Mawardi,1978:126.Fay' merupakan sumber penerimaan dari negara Islam dan sumberpembiayaan negara. ). Harta fa'I digunakan untuk kepentingan pemerintahan dan kesejahteraan umat (Chaundry, 2016:128. Ketentuan tentang fa'i ini dapat dilihat dalam al-Qur'ansurat al-Hasyar ayat 6-7: "apa saja harta rampasan (fai-i) yang diberikan Allah kepada RasulNya(dari harta benda) yang berasal dari penduduk kota-kota Maka adalahuntuk Allah, untuk rasul, kaum kerabat, anak-anak yatim, orangorangmiskin dan orang-orang yang dalam perjalanan, supaya harta itu janganberedar di antara orang-orang Kaya saja di antara kamu. apa yangdiberikan Rasul kepadamu, Maka terimalah. dan apa yang dilarangnyabagimu, Maka tinggalkanlah. dan bertakwalah kepada Allah. SesungguhnyaAllah Amat keras hukumannya."(QS. Al Hasyr [59]: 6-7)

\section{Ghanimah}

Pada masa-masa pemerintahan Islam di Madinah (623 M) atau tahun1Hijriah, pendapatan dan pengeluaran negara hampir tidak ada. Rasullah sendiri adalah seorang kepala Negara. Pada fase awal ini, hampir seluruh pekerjaan yangdilakukan tidak mendapat upah sebab pada masa ini umat Islam baru mendirikan ppemerintahan Islam - Situasi mulai berubah, setelah turunnya surat Al-Anfal (Rampasan Perang). Pada waktu perang badar di tahun 2 hijriah,sejak itu negara mulai mempunyai pendapatan dari hasil rampasan perang(ghanimah) yang disebut dengan khumz (seperlima), berupa kuda, unta, danbarang-barang bergerak lainnya yang didapatkan dalam peperangan. Sumber pendapatan Negara saaati itu adalah Ghanimah. ghanimah (barang rampasan perang) merupakan kekayaan yang dirampas dari orang-orang non muslim 
setelah perang usai (Ibnu Taimiyah.1963:46). Kemudian Rasulloh SAW mengelolah ghanimah sebagai sumber pendapatan untuk membantu umat muslim pada saat itu.

\section{Kharaj}

Pada masa Rasulullah SAW dan kekhalifahan Islam, pajak merupakan salah satu sumber pendapatan negara dari selain zakat, kekayaan yang diperoleh dari musuh tanpa perang (fay'), harta wakaf, barang temuan (luqatah)dan dari kekayaan alam. Pajak dalam Islam terbagi atas 3 macam yaitu jizyah(pajak kepala), kharaj(pajak bumi), dan 'usyur (pajak atau bea cukai atas barang ekspor dan impor).

Dalam terminologi keuangan Islam, kharaj adalah pajak atast anah atau hasil tanah, dimana para pengelola wilayah taklukan harus membayar kepada negara islam. Negara Islam setelah penaklukan adalah pemilik atas wilayah itu, dan pengelola harus membayar sewa kepada negara Islam.dengan ketatapan kharaj ini dapat menjadikan sumber pendapatan Negara Islam.

Peristiwa sejarah yang terjadi di zaman Rasulullah saw. menginspirasi Abu Yusuf untuk senantiasa mengembangkan pemikiran-pemikiran yang terkait dengan perpajakan, agar keberadaannya betul-betul dapat memberikan manfaat bagi umat. Pemerintah dapat melaksanakan kewajibannya secara baik dan rakyat dapat menikmatinya dengan nyaman tanpa ada unsur kezalimanan. Abu Yusuf cenderung menyetujui negara mengambil bagian dari hasil pertanian dari para penggarap daripada menarik sewa dari lahan pertanian. Dalam pandangannya, cara ini lebih adil dan tampaknya akan memberikan hasil produksi yang lebih besar dengan memberikan kemudahan dalam memperluas tanah garapan (Abu yusuf: 1979: 117).

5. Jizyah

Pada masa Rasulullah juga sudah terdapat jizyah, yaitu pajak kepala yang dibayarkan oleh orang non-Muslim khususnya ahli kitab, untuk jaminan perlindungan jiwa, properti, ibadah, bebas dari nilai-nilai, dan tidak wajib militer. Besarnya jizyah satu dinar per tahun untuk orang dewasa yang mampu membayarnya.Untuk pengambilan jizyah ini, umat islam dianjurkan untuk berlemah lembut dan tidak diperbolehkan bersikap kasar kepada mereka.Abu Ubaid mengatakan bahwa tidakkah engkau melihat bahwa pernah dimbil dari mereka sehelai pakaian (atau al-maa'fir atau tempat untuk menyimpan uang dinar ) ini tidak lain dimaksudkan sebagai kemudahan bagi ahli dzimmah, dan tidak boleh dijual akan tetapi , diambil hanya sekedar nilai yang murah lagi bagi mereka.Tidaklah engkau mendengar perkataan Rasululloh SAW 'atau gantilah jizyah itu dengan nilai yang seumpama dengannya (Abu Ubaid. 2006:111).Ibnu Taimiyah m

Adapun pengeluaran keuangan Negara menurut Ibnu Taimiyah(19 63:275-278) adalah sebagaiberikut: (1) orang-orang miskin dan orang-orang melarat, (2) untuk 
meningkatkankemampuan pasukan dalam memelihara keamanan, (3) memelihara hukum dan tatanan dalam negeri, (4)gaji atau upah, (5) pendidikan, (6)pengembangan infrastruktur, (7) kesejahteraan umum. Ibnu Taymiyyah juga berpendapat bahwa penggunaankeuangan harus benar-benar dipergunakan seperti yang dianjurkan oleh Allah danRasul-Nya (Ibnu Taimiyah. 1963:31)

\section{KESIMPULAN}

Dari uraian diatas ppenulis dapat mengambil kesimpuln bahwa keuangan public dalam perspektif Ekonomi Islam islam terdiri dari sumber pendapatan Negara dan sumber pengeluaran Negara. Adapun Sumber pendapatan terdiri dari: 1). zakat 2).Fa'I 3). Ghanimah 4). Kharaj dan 5) jizyah. Sedangkan, sumber pengeluaran Negara dalam persfektip Ekonomi Islam(1) orang-orang miskin dan orang-orang melarat, (2) untuk meningkatkankemampuan pasukan dalam memelihara keamanan, (3) memelihara hukum dan tatanan dalam negeri, (4) gaji atau upah, (5) pendidikan, (6) pengembangan infrastruktur, (7) kesejahteraan umum.

Konsep keuangan Publik dalam persfektif ekonomi Islam dapat dijadikan refrensi dalam mengelolah keuangan dinegar kita. Hal ini sudah terbukti awal pemerintah Islam 1 hijriah bahwa umat Islam tidak memiliki kekayaan negara, tetapi dengan konsep ekonomi Islam yang diterapkan bisa menjadi pengendali dunia.Sumber pendapatan terbesar di Negara Indonesia adalah pajak . apabila pajak dan zakat ini dikelolah dengan adil,jujur dan transparan sesuai dengan prinsip syaiah. penulis yakin bahwa Indonesia dapat menjadi Negara maju bahkan menjadi Negara adikuasa di seluruh dunia.

\section{SARAN}

Setelah peneliti memaparkan hal- hal yang berkaitan dengan konsep Ekonomi . Islam dalam mengelolah keuangan public . Selanjutnya peneliti akan memberikan saran sebagai berikut: Penelitian ini baru menjangkau kajian konsep ekonomi Islam berdasarkan data konseptual dari para pemikir ekonom muslim. Sehingga perlu kajian lanjutan konsep ekonomi Islam berdasarkan pedoman praktisnya dalam lapangan empiris. Peneliti menyadari bahwa penelitian ini masih banyak kekurangan, khususnya mengenai konsep ekonomi Islam dalam keuangan public. Kekurangan ini diharapkan dapat dilengkapi peneliti lain 


\section{DAFTAR PUSTAKA}

Al Qasim, Abu Ubaid. 2006. Kitab al Amwal, Beirut: Dar al Fikr.

Al-Haritsi, Jaribah bin Ahmad, 2006. Fikih Ekonomi Umar bin Khattab, Penerjamah H. Asmuni Solihan Zamakhsyari, Jakarta: Khallifah

Al-Mawardi.1978.al-Ahkam al-Sulthaniyyah.Beirut: Dar al-Kutub.

Chaundhry, Muhammad Sharif, 2011. Sistem Ekonomi Islam, Jakarta: Prenada Media Group

Harvey S. Rossen, Public Finance: Essay for the Encyclopedia of Public Choice (Princeton

Hasbi Ash-Shiddieqy.1984. Pedoman Zakat, Jakarta: PT. Bulan Bintang, Cet. V, 1984.

Ibn Manzhur,Lisan al-'Arab(Mesir: al-Dar al-Mishriyyah, tt).

Ibnu Manzur.1990. Lisan al-Arab, Jilid II, Beirut-Libanon: Dar Sader, 1990.

Mahmud Muhammad Bablily.1990 Etika Bisnis: Studi Kajian Konsep Perekonomian Menurut al-Qur'an dan as-Sunnah, terj. Rosihin A. Ghani, Solo: Ramadhani.

Muslimin H. Kara.2005. Bank Syariah Di Indonesia Analisis Terhadap Pemerintah Indonesia Terhadap Perbankan Syariah, Yogyakarta: UII Press.

Nia K. Winayanti.2015. Hand-out Pengertian Keuangan Negara, FH Unpas.

Ofan El-Govhar" Keseimbangan IS-LM dalam Perspektif Islam”. diakses pada 09 Desember 2009. Dari http://djophan.blogspot.com/2009/04/bab-i-pendahuluan.html

Pusat Pengkajian dan Pengembangan Ekonomi Islam (P3EI). 2011.Ekonomi Islam, Jakarta: PT Raja Grafindo Persada, 2011.

Soediyono R..1992 Ekonomi Makro Pengantar Analisis Pendapatan Nasional Yogyakarta: Liberty.

Yusuf, Abu . Kitab al-Kharaj. Beirut: Dar al-Ma"arif, 1979 